\title{
MODEL VOLUME POHON SENGON UNTUK MENILAI KEHILANGAN KEUNTUNGAN PETANI HUTAN RAKYAT
}

\author{
Volume Model of Sengon Tree to Evaluate the Profit Loss \\ for Community Forest's Farmer \\ Ari Ardelina ${ }^{1)}$, Tatang Tiryana ${ }^{2)}$ dan/and Muhdin ${ }^{2)}$

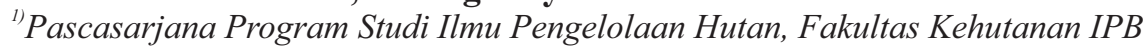 \\ ${ }^{2}$ Departemen Manajemen Hutan, Fakultas Kehutanan IPB \\ Email: ariardelina@gmail.com \\ Program Studi Ilmu Pengelolaan Hutan, Fakultas Kehutanan, Kampus IPB Darmaga, \\ Bogor, Jawa Barat, Indonesia \\ Email: tantir@gmail.com ${ }^{2}$
}

Tanggal diterima: 23 Januari 2015; Tanggal direvisi: 29 Juli 2015; Tanggal disetujui: 5 Agustus 2015

\begin{abstract}
Selling system of sengon (Paraserianthes falcataria L.) timber in community forests without using appropriate tree volume models may generate profit loss for the farmers. The objectives of this study were to develop volume models of sengon and to evaluate the profit losses of commonly practiced techniques for selling the sengon timber in community forest. The result showed that the proposed volume model can be used accurately to estimate the volume of sengon trees in the community forest by measuring tree diameters. This study confirmed that the selling system based on per log and total stand area caused profit losses of $24.99 \%$ and $32.19 \%$ respectively, to the farmers. To avoid such disadvantages, therefore the use of the proposed volume model is recommended to facilitate accurate estimation of the volume of sengon trees.
\end{abstract}

\section{Keywords: Community forest, profit loss, volume models}

\begin{abstract}
ABSTRAK
Sistem penjualan pohon sengon (Paraserianthes falcataria L.) di hutan rakyat tanpa menggunakan model volume pohon yang tepat dapat menimbulkan kehilangan keuntungan petani. Tujuan penelitian ini adalah untuk memperoleh model volume sengon dan mengevaluasi praktek yang biasa dilakukan dalam penjualan kayu sengon di hutan rakyat. Hasil penelitian menunjukkan bahwa model volume yang dapat digunakan secara akurat untuk memperkirakan volume pohon sengon di hutan rakyat dapat diduga dengan hanya mengukur diameter pohon. Sistem penjualan berdasarkan batangan dan luasan menyebabkan petani kehilangan keuntungan sebesar 24,99\% dan $32,19 \%$. Untuk menghindari kelemahan tersebut maka direkomendasikan model volume sebagai penduga volume pohon sengon dengan akurat.
\end{abstract}

Kata kunci: Hutan rakyat, kehilangan keuntungan, model volume

\section{PENDAHULUAN}

Pentingnya kelestarian sumberdaya hutan bagi kehidupan baik dari aspek ekonomi, ekologi maupun sosial semakin meningkat karena hutan alam mengalami penurunan yang signifikan dari segi kuantitas dan kualitasnya. Upaya yang dapat dilakukan untuk menunjang kelestarian ketiga aspek tersebut adalah pembangunan hutan rakyat pada lahan-lahan milik yang dikelola oleh masyarakat.

Saat ini penelitian mengenai hutan rakyat lebih banyak mengkaji aspek sosial ekonomi, misalnya Kusmedi et al. (2010) mengkaji analisis finansial pengelolaan hutan rakyat, Prihadi et al. (2010) menilai kelembagaan kemitraan industri pengolahan kayu di hutan rakyat. Sedangkan aspek perencanaan pengelolaan belum banyak dikembangkan. Salah satu aspek yang masih perlu diteliti adalah efektifitas pendugaan potensi pohon dan tegakan di hutan rakyat. Kurangnya pengetahuan masyarakat dalam menduga potensi pohon dan tegakan dapat menimbulkan kesalahan perhitungan nilai kayu saat penjualan sehingga mengakibatkan kerugian ekonomi bagi petani hutan rakyat. 
Potensi tegakan dapat diduga dengan menggunakan model penduga volume pohon. Salah satu jenis tegakan yang banyak dikembangkan di hutan rakyat adalah sengon (Paraserianthes falcatria L.). Beberapa peneliti telah mengembangkan model-model penduga volume untuk hutan tanaman sengon. Misalnya, Bustomi et al. (1995) menyusun model penduga volume pohon sengon untuk hutan tanaman di Jonggol, Jawa Barat. Kurinobu et al. (2007) menyusun persamaan taper untuk menduga volume pohon sengon pada hutan tanaman di Pare, Jawa Timur. Namun untuk hutan rakyat, model-model penduga volume pohon sengon belum banyak dikembangkan sesuai dengan karakteristik tiap lokasi hutan rakyat yang pengelolaannya cenderung beragam (Bramasto \& Tiryana 2013).

Ketersediaan alat penduga volume pohon (misalnya model volume) diperlukan untuk mendukung sistem penjualan kayu di hutan rakyat. Saat ini penjualan kayu di hutan rakyat umumnya dilakukan dengan sistem batangan dan borongan/ tebasan (Diniyati et al., 2009). Sistem penjualan batangan dilakukan petani berdasarkan jumlah batang pohon, sedangkan sistem penjualan borongan/tebasan dilakukan petani dengan menjual luasan areal tertentu. Pada kedua sistem penjualan tersebut harga kayu tidak ditentukan berdasarkan volume pohon, melainkan berdasarkan taksiran harga per batang pohon (untuk sistem penjualan batangan) dan taksiran harga total tegakan (untuk sistem penjualan borongan/tebasan) yang biasanya ditentukan secara sepihak oleh tengkulak. Sistem penjualan kayu seperti itu berpotensi merugikan petani, karena sangat mungkin terjadi kesalahan dalam pendugaan volume kayu yang dapat mengakibatkan kehilangan keuntungan petani hutan rakyat.

Salah satu sumber kesalahan (error) dalam pendugaan volume kayu di hutan rakyat adalah alat penduga volume pohon. Selain menggunakan model volume, pendugaan volume pohon dapat dilakukan dengan menggunakan angka bentuk pohon dan persamaan taper pohon (Husch et al., 2003). Ketelitian dari alat-alat penduga volume pohon tersebut perlu dianalisis untuk mengetahui besarnya kesalahan pendugaan volume kayu di hutan rakyat. Chave et al. (2004) menunjukkan bahwa kesalahan dalam pengukuran pohon dan pemilihan model penduga biomassa pohon menyebabkan terjadinya perambatan kesalahan (error propagation) dalam pendugaan biomassa tegakan di hutan tropis.
Saat ini belum banyak penelitian yang menganalisis ketelitian penggunaan alat-alat penduga volume pohon dalam kaitannya dengan potensi kehilangan pendapatan finansial petani, khususnya untuk hutan rakyat sengon. Oleh karena itu, penelitian ini bertujuan untuk menyusun model volume pohon sengon dan membandingkan ketelitiannya dengan alat-alat penduga volume lain (yaitu angka bentuk pohon dan persamaan taper) serta menganalisis potensi kehilangan keuntungan petani dari penjualan kayu sengon di hutan rakyat.

\section{METODOLOGI}

\section{A. Lokasi Penelitian}

Penelitian ini dilaksanakan di hutan rakyat sengon di Desa Karyasari, Kecamatan Leuwiliang, Kabupaten Bogor, Jawa Barat. Desa ini terletak $9 \mathrm{~km}$ dari pusat kota Kecamatan Leuwiliang, $42 \mathrm{~km}$ dari pusat kota Bogor dan $75 \mathrm{~km}$ dari ibukota Provinsi Jawa Barat. Luas wilayah desa Karyasari \pm 621 Ha yang terletak pada ketinggian 600-700 $\mathrm{m}$ dari permukaan laut (Pemerintah Daerah Bogor, 2010).

\section{B. Pengumpulan Data}

Pengumpulan data dilakukan pada bulan April sampai Juni 2014 untuk memperoleh data volume pohon contoh dan data penjualan kayu sengon. Data volume pohon contoh diperoleh dari hasil pengukuran 168 pohon sengon yang dipilih secara purposif dengan kriteria berbatang lurus, tumbuh sehat, dan mewakili sebaran diameter tegakan sengon di hutan rakyat. Pada tiap pohon contoh dilakukan pengukuran diameter batang pada ketinggian 1,3 $\mathrm{m}$ (disebut diameter setinggi dada, Dbh) dengan menggunakan phiband, pengukuran diameter per seksi batang (panjang $1 \mathrm{~m}$ ), tinggi bebas cabang dan tinggi total pohon dengan menggunakan Criterion RD 1000, pengukuran jarak datar dengan menggunakan Laser Rangefinder.

Data pohon untuk menghitung potensi kerugian diperoleh melalui pegukuran pohon dari areal hutan rakyat seluas $500 \mathrm{~m}^{2}$, dengan menghitung seluruh tegakan sengon (43 pohon) untuk sistem borongan dan satu pohon untuk sistem batangan. Pada tiap pohon dilakukan pengukuran Dbh, diameter per seksi batang (panjang $1 \mathrm{~m}$ ), tinggi bebas cabang, dan tinggi total pohon. Data 
penjualan kayu sengon diperoleh melalui wawancara dengan petani dan pengepul, karena pada saat penelitian tidak ada praktik penjualan kayu yang dilakukan oleh petani. Wawancara dilakukan terhadap 20 petani sengon dari beberapa kelompok tani di Desa Karyasari untuk mengetahui praktik penjualan kayu yang biasa dilakukan dan mengetahui potensi pendapatan petani dari praktik tersebut. Wawancara terhadap pengepul dilakukan untuk memperoleh taksiran harga kayu jika penjualan dilakukan dengan sistem batangan dan sistem borongan/tebasan untuk menganalisis potensi pendapatan petani dari sistem penjualan kayu sengon tersebut.

\section{Penentuan Volume dan Angka Bentuk Pohon}

Volume pohon contoh $\left(V, \mathrm{~m}^{3}\right)$ ditentukan melalui penjumlahan volume tiap seksi batang $\left(v_{i}, \mathrm{~m}^{3}\right)$ berdasarkan luas penampang lintang pangkal seksi $\left(g_{p}, \mathrm{~m}^{2}\right)$, luas penampang lintang ujung seksi $\left(g_{u}, \mathrm{~m}^{2}\right)$, dan panjang seksi $(l, \mathrm{~m})$ dengan menggunakan rumus Smalian sebagai berikut (Husch et al., 2003):

$V=\sum_{i=1}^{n} v_{i}$ dan $v_{i}=\frac{g_{p}+g_{u}}{2} \mathbf{l}$

Untuk analisis data selanjutnya, data pohon contoh dibagi menjadi dua bagian (Tabel 1), yaitu data model untuk penyusunan alat-alat penduga volume pohon (angka bentuk, persamaan taper, model volume) dan data validasi untuk menilai ketelitian alat-alat penduga volume pohon.

Dalam penelitian ini dianalisis dua macam angka bentuk, yaitu angka bentuk absolut dan buatan yang dihitung dengan rumus (Simon, 1996):

$$
\begin{aligned}
& f_{a}=\frac{V a}{V d p} \\
& f_{a}=\frac{V a}{V d p}
\end{aligned}
$$

\section{Penyusunan Persamaan Taper}

Persamaan taper disusun berdasarkan data diameter per seksi $(d, \mathrm{~cm})$ dan tinggi batang per seksi $(h, \mathrm{~m})$ dari pohon contoh melalui analisis regresi. Persamaan taper yang sesuai untuk menggambarkan bentuk batang sengon dipilih dari persamaan-persamaan berikut ini (Muhdin \& Hakim, 2004): $(\mathrm{d} / \mathrm{D})=\mathrm{f}(\mathrm{h} / \mathrm{H})$

$(\mathrm{d} / \mathrm{D})=\mathrm{f}\left\{(\mathrm{h} / \mathrm{H}),(\mathrm{h} / \mathrm{H})^{2}\right\}$

$(\mathrm{d} / \mathrm{D})=\mathrm{f}\left\{(\mathrm{h} / \mathrm{H}),(\mathrm{h} / \mathrm{H})^{2},(\mathrm{~h} / \mathrm{H})^{3}\right\}$

$(\mathrm{d} / \mathrm{D})^{2}=\mathrm{f}\{(\mathrm{h} / \mathrm{H})$

$(\mathrm{d} / \mathrm{D})^{2}=\mathrm{f}\{(\mathrm{h} / \mathrm{H})$

$(\mathrm{d} / \mathrm{D})^{2}=\mathrm{f}\left\{(\mathrm{h} / \mathrm{H}),(\mathrm{h} / \mathrm{H})^{2},(\mathrm{~h} / \mathrm{H})^{3}\right\}$

Persamaan volume disusun dengan cara mengintegralkan persamaan taper terpilih dengan tinggi batang per seksi sampai diameter batang $7 \mathrm{~cm}(\mathrm{H})$ :

$$
V=\frac{1}{4} \pi \int_{h=0}^{H} d^{2} d h
$$

\section{E. Penyusunan Model Volume}

Model volume pohon sengon disusun dengan menggunakan satu peubah bebas (diameter pohon) dan dua peubah bebas (diameter dan tinggi pohon). Model-model regresi yang dianalisis adalah (Simon, 1996):

$\mathrm{V} 1=\mathrm{b}_{0}+\mathrm{b}_{1} \mathrm{D}^{2}$ (Kopezky-Gehrhardt)

$\mathrm{V} 2=\mathrm{b}_{0}+\mathrm{b}_{1} \mathrm{D}+\mathrm{b}_{2} \mathrm{D}^{2}$ (Hohenadl-Krenn) ..

$\mathrm{V} 3=\mathrm{b}_{0} \mathrm{D}^{\mathrm{b} 1}$

(Berkhout)

$\mathrm{V} 4=\mathrm{b}_{0} \mathrm{D}^{\mathrm{b} 1} \mathrm{H}^{\mathrm{b} 2}$

(Schumacher)

$\mathrm{V} 5=\mathrm{b}_{0}+\mathrm{b}_{1} \mathrm{D}^{2} \mathrm{H} \quad$ (Spurr)

$\mathrm{V} 6=\mathrm{b}_{0}+\mathrm{b}_{1} \mathrm{D}^{2}+\mathrm{b}_{2} \mathrm{D}^{2} \mathrm{H}+\mathrm{b}_{3} \mathrm{H}$ (Stoate)

Parameter model V3 dan V4 diperoleh melalui transformasi logaritma menjadi model linier. Transformasi balik ke bentuk model semula menyebabkan bias, sehingga parameter $b_{0}$ pada model-model tersebut harus dikoreksi dengan nilai kuadrat tengah sisaan (standard error of estimate, $S E E$ ) melalui rumus berikut ini (Sprugel, 1983):

$\mathrm{CF}=\exp \left(S E E^{2} / 2\right)$

Penilaian kesesuaian (goodness of fit) modelmodel regresi dilakukan dengan menguji signifikansi parameter model (Yang et al., 2004) dan membandingkan nilai root mean square error (RMSE) dan koefisien determinasi terkoreksi $\left(\mathrm{R}_{\text {adi }}^{2}\right)$ dengan rumus sebagai berikut (Draper \& Smith 1992, Huang et al. 2003):

$$
\begin{aligned}
& \mathrm{RMSE}=\sum_{i=1}^{x} \frac{\sqrt{(y i-\hat{\mathrm{y}} i)^{2}}}{n-p} \\
& \mathrm{R}_{a d j}^{2}=1-\frac{(n-1)=\sum_{i=1}^{n}\left(y_{i}-\hat{\mathbf{y}}_{i}\right)^{2}}{(n-p)=\sum_{i=1}^{n}\left(y_{i}-\bar{y}_{i}\right)^{2}} .
\end{aligned}
$$

Tabel 1. Deskripsi statistik pohon contoh (Descriptive statistics of sample trees)

\begin{tabular}{lrrrrrrrc}
\hline \multirow{2}{*}{ Variabel } & \multicolumn{3}{c}{ Data model $(n=100)$} & \multicolumn{4}{c}{ Data Validasi $(n=68)$} \\
\cline { 2 - 9 } & Mean & SD & Min & Max & Mean & SD & Min & Max \\
\hline $\mathrm{D}(\mathrm{cm})$ & 22,05 & 8,57 & 10,10 & 50,90 & 26,40 & 9,05 & 12,00 & 51,00 \\
$\mathrm{H}(\mathrm{m})$ & 13,27 & 4,15 & 6,00 & 23,30 & 16,83 & 3,96 & 6,20 & 23,1 \\
$\mathrm{Va}\left(\mathrm{m}^{3}\right)$ & 0,40 & 0,39 & 0,04 & 2,18 & 0,61 & 0,45 & 0,08 & 2,20 \\
\hline
\end{tabular}

Sumber (Source): Diolah dari data lapang (Compiled and analyzed from field data) 
Keterangan(Remarks): yi, $\hat{y}, \bar{y}=$ volume aktual, volume dugaan model, rata-rata volume aktual; $n=$ jumlah data; $p=$ jumlah parameter model

Model volume pohon terpilih adalah model yang memiliki nilai RMSE terkecil, dan $\left(\mathrm{R}_{a d j}^{2}\right)$ terbesar. Selain itu model tersebut harus memenuhi asumsi kenormalan sisaan dan homogenitas sisaan.

\section{F. Validasi Alat-alat Penduga Volume Pohon}

Alat-alat penduga volume pohon (angka bentuk, persamaan taper, dan model volume) selanjutnya digunakan untuk menduga volume pohon contoh dan membandingkan ketelitian pendugaannya dengan menggunakan data validasi (Tabel 1). Sebagai pembanding, dinalisis pula ketelitian model volume pohon sengon yang dikembangkan oleh Bustomi (1995) berikut ini:

$\log V_{B}=-3,859+2,4798 \log D$

Adapun kriteria statistik yang digunakan dalam validasi alat-alat penduga volume tersebut adalah mean error (ME), percentage error (PE\%), mean absolute difference (MAD), mean square error of prediction (MSEP), relative error in prediction $(R E \%)$, dan modeling efficiency $(E F)$, yang dihitung sebagai berikut (Huang et al. 2003, Tiryana et al., 2011):

$$
\begin{gathered}
\mathrm{ME}=\frac{\sum_{i=1}^{n}\left(y_{i}-\hat{\mathrm{y}}_{i}\right)^{2}}{n}(7 \mathrm{a}) \quad \mathrm{MSEP}=\frac{\sum_{i=1}^{n}\left(y_{i}-\hat{\mathrm{y}}_{i}\right)^{2}}{n} \\
\mathrm{PE} \%=\frac{100 . \bar{e}}{\sum_{i=1}^{n} y_{i} / n} \quad(7 \mathrm{~b}) \quad \mathrm{RE} \%=\frac{100 \sqrt{M S E P}}{\overline{\mathrm{y}}} \\
\mathrm{ME}=\frac{\sum_{i=1}^{n}\left(y_{i}-\hat{\mathrm{y}}_{i}\right)^{2}}{n} \quad(7 \mathrm{c}) \quad \mathrm{EF}=1-\frac{\sum_{i=1}^{n}\left(y_{i}-\hat{\mathrm{y}}_{i}\right)^{2}}{\sum_{i=1}^{n}\left(y_{i}-\bar{y}_{i}\right)^{2}}
\end{gathered}
$$

ME, $\mathrm{PE} \%$ dan MAD mengukur bias atau keakuratan model, sedangkan MSEP, RE\%,dan
EF mengukur ketelitian dari model pendugaan (Huang et al., 2003).

\section{G. Analisis Potensi Kehilangan Keuntungan Petani}

Potensi kehilangan keuntungan petani dari penjualan kayu sengon dianalisis dengan mensimulasikan sistem penjualan batangan dan borongan/tebasan. Untuk sistem penjualan batangan, harga kayu taksiran pengepul dibandingkan dengan harga kayu seharusnya yang dihitung berdasarkan volume pohon dengan menggunakan alat penduga volume pohon terpilih. Untuk sistem penjualan borongan, total harga tegakan pada luasan $500 \mathrm{~m}^{2}$ dari taksiran pengepul dibandingkan dengan total harga tegakan seharusnya yang dihitung berdasarkan penjumlahan volume per pohon dengan menggunakan alat penduga volume terpilih. Pada kedua simulasi sistem penjualan tersebut, potensi kehilangan keuntungan petani dihitung sebagai selisih antara taksiran harga kayu dari pengepul dengan harga pasar kayu (per $\mathrm{m}^{3}$ ), dengan memperhitungkan harga pemanenan kayu yang dikeluarkan oleh pengepul.

\section{HASIL DAN PEMBAHASAN}

\section{A. Hasil}

\section{Angka bentuk pohon sengon}

Pohon sengon di hutan rakyat memiliki ratarata angka bentuk buatan $(0,647)$ yang relatif lebih besar dibanding angka bentuk absolutnya (0,550, Tabel 2). Namun angka bentuk buatan pohon sengon tersebut cenderung lebih seragam $(C V=16 \%)$ dibanding angka bentuk absolutnya $(C V=19 \%)$.

Tabel (Table) 2. Deskriptif statistik angka bentuk absolut dan buatan pohon sengon (Descriptive statistics of absolute and artificial form factor from sengon tree)

\begin{tabular}{cccccc}
\hline $\begin{array}{c}\text { Angka Bentuk } \\
\text { (Form factor) }\end{array}$ & Min & Max & Mean & SD & CV (\%) \\
\hline Absolut & 0,324 & 0,844 & 0,550 & 0,102 & 19 \\
Buatan & 0,386 & 0,861 & 0,647 & 0,103 & 16 \\
\hline
\end{tabular}

Sumber (Source): Diolah dari data lapang (Compiled and analyzed from field data) 
Tabel 3. Persamaan Taper Pohon Sengon (Taper equations of sengon tree)

\begin{tabular}{clcccc}
\hline No & \multicolumn{1}{c}{ Persamaan (Equations) } & $s$ & $R^{2}$ & $R^{2}$ adj & $P$-value \\
\hline 1 & $\mathrm{~d} / \mathrm{D}=1,04-0,533 \mathrm{~h} / \mathrm{H}$ & 0,093 & $74,10 \%$ & $74,10 \%$ & $<0,0001$ \\
2 & $\mathrm{~d} / \mathrm{D}=1,06-0,648 \mathrm{~h} / \mathrm{H}+0,105(\mathrm{~h} / \mathrm{H})^{2}$ & 0,093 & $74,30 \%$ & $74,30 \%$ & $<0,0001$ \\
3 & $\mathrm{~d} / \mathrm{D}=1,05-0,544 \mathrm{~h} / \mathrm{H}-0,128(\mathrm{~h} / \mathrm{H})^{2}+0,143(\mathrm{~h} / \mathrm{H})^{3}$ & 0,093 & $74,30 \%$ & $74,30 \%$ & $<0,0001$ \\
4 & $(\mathrm{~d} / \mathrm{D})^{2}=1,01-0,781 \mathrm{~h} / \mathrm{H}$ & 0,123 & $77,80 \%$ & $77,80 \%$ & $<0,0001$ \\
5 & $(\mathrm{~d} / \mathrm{D})^{2}=1,11-1,26 \mathrm{~h} / \mathrm{H}+0,437(\mathrm{~h} / \mathrm{H})^{2}$ & 0,119 & $79,40 \%$ & $79,40 \%$ & $<0,0001$ \\
6 & $(\mathrm{~d} / \mathrm{D})^{2}=1,11-1,26 \mathrm{~h} / \mathrm{H}+0,441(\mathrm{~h} / \mathrm{H})^{2}-0,002(\mathrm{~h} / \mathrm{H})^{3}$ & 0,119 & $79,40 \%$ & $79,30 \%$ & $<0,0001$ \\
\hline
\end{tabular}

Sumber (Source): Diolah dari data lapang (Compiled and analyzed from field data)

\section{Persamaan taper pohon sengon}

Keenam persamaan taper bersifat sangat nyata $(\mathrm{P}$-value $<0,01)$, yang berarti bahwa peubah tinggi dapat menduga peubah diameter pada berbagai ketinggian batang pohon. Namun, berdasarkan nilai koefisien determinasi $\left(\mathrm{R}_{\text {adj }}^{2}=\right.$ $79,4 \%)$ dan nilai simpangan baku $(s=0,119)$, persamaan taper terbaik adalah persamaan kelima: $\left.(\mathrm{d} / \mathrm{D})^{2}=1,11-1,26 \mathrm{~h} / \mathrm{H}+0,437 \mathrm{~h} / \mathrm{H}\right)^{2}($ Tabel 3). Dari hasil integrasi taper persamaan tersebut diperoleh model volume pohon sebagai berikut:

$$
\mathrm{V}_{\mathrm{T}}=0,4911 \mathrm{D}^{2} \mathrm{H}
$$

\section{Model volume pohon sengon}

Semua parameter pada model persamaan V1, V3, V4 dan V5 bersifat nyata $(\mathrm{P}-$ value $<0,05)$, yang berarti bahwa peubah diameter (pada model V1 dan V3) atau peubah diameter dan tinggi (pada model V4 dan V5) dapat digunakan untuk menduga volume pohon(Tabel 4). Model-model tersebut dapat menjelaskan keragaman volume pohon sebesar 96-98\%. Model V4 memiliki nilai RMSE terkecil $(0,056)$ walaupun tidak berbeda jauh dengan model V3 (RMSE $=0,077)$. Uji Kolmogorov-Smirnov menunjukkan bahwa model V3 $(\mathrm{P}-$ value $=0,133)$ dan V4 $(\mathrm{P}-$ value $=0,150)$ memenuhi asumsi kenormalan sisaan (pada taraf nyata $5 \%$ ). Analisis sisaan juga menunjukkan bahwa model V3 dan V4 memenuhi asumsi kehomogenan ragam sisaan. Dengan demikian, model V3 dan V4 merupakan model-model volume terbaik dibandingkan model-model lainnya yang tidak memenuhi asumsi kenor-malan sisaan dan kehomogenan ragam sisaan.

Tabel(Table)4. Nilai-nilai parameter dan kriteria statistik untuk model-model volume (Parameter estimates and criteria statistics of volume models)

\begin{tabular}{|c|c|c|c|c|c|c|c|c|c|c|}
\hline Model & & Parameter & SE & P-value & RMSE & $\mathrm{R}^{2}(\%)$ & $\begin{array}{c}\mathrm{R}^{2} \mathrm{adj} \\
(\%)\end{array}$ & $\mathrm{S}$ & $\begin{array}{l}\text { Normalitas sisaan } \\
\text { (Normality of } \\
\text { residuals) }\end{array}$ & $\begin{array}{c}\text { Homogenitas } \\
\text { ragam sisaan } \\
\text { (Homogeneity of } \\
\text { variance residuals) }\end{array}$ \\
\hline \multirow[t]{2}{*}{ V1 } & b0 & $-0,0715$ & 0,01228 & $<0,0001$ & 0,163 & 96,10 & 96,10 & 0,078 & Tidak (No) & Tidak (No) \\
\hline & b1 & 0,000842 & 0,00001704 & $<0,0001$ & & & & & & \\
\hline \multirow[t]{3}{*}{ V2 } & b0 & 0,0564 & 0,0501 & 0,263 & 0,075 & 96,40 & 96,30 & 0,075 & Tidak (No) & Tidak (No) \\
\hline & b1 & $-0,0108$ & 0,004115 & 0,010 & & & & & & \\
\hline & b2 & 0,00104 & 0,00007709 & $<0,0001$ & & & & & & \\
\hline \multirow[t]{2}{*}{ V3 } & b0 & 0,000213 & 0,1297 & $<0,0001$ & 0,077 & 96,90 & 96,90 & 0,069 & Terpenuhi & Terpenuhi \\
\hline & b1 & 2,37 & 0,04259 & $<0,0001$ & & & & & (Yes) & (Yes) \\
\hline \multirow[t]{3}{*}{ V4 } & b0 & 0,000147 & 0,09033 & $<0,0001$ & 0,056 & 98,70 & 98,70 & 0,045 & Terpenuhi & Terpenuhi \\
\hline & b1 & 1,94 & 0,04602 & $<0,0001$ & & & & & (Yes) & (Yes) \\
\hline & b2 & 0,644 & 0,05594 & $<0,0001$ & & & & & & \\
\hline \multirow[t]{2}{*}{ V5 } & b0 & 0,0655 & 0,008366 & $<0,0001$ & 0,063 & 97,40 & 97,40 & 0,063 & Tidak (No) & Tidak (No) \\
\hline & b1 & 0,000037 & 0,00000061 & $<0,0001$ & & & & & & \\
\hline \multirow[t]{4}{*}{ V6 } & b0 & $-0,072$ & 0,02882 & 0,014 & 0,054 & 98,20 & 98,10 & 0,054 & Tidak (No) & Tidak (No) \\
\hline & b1 & 0,00033 & 0,00005717 & $<0,0001$ & & & & & & \\
\hline & b2 & 0,000021 & 0,00000276 & $<0,0001$ & & & & & & \\
\hline & b3 & 0,0077 & 0,002389 & 0,002 & & & & & & \\
\hline
\end{tabular}

Sumber (Source): Diolah dari data lapang (Compiled and analyzed from field data) 
Tabel (Table)5. Nilai-nilai statistik hasil uji validasi model-model penduga volume pohon (Validation statistics of tree volume models)

\begin{tabular}{lcccccc}
\hline \multicolumn{1}{c}{ Model } & ME & PE $(\%)$ & MAD & MSEP & RE (\%) & EF \\
\hline V3 & 0,019 & 3,146 & 0,073 & 0,009 & 1,450 & 0,955 \\
V4 & 0,009 & 1,545 & 0,049 & 0,006 & 0,918 & 0,972 \\
V fa & $-0,005$ & $-0,824$ & 0,066 & 0,011 & 1,747 & 0,946 \\
V fb & $-0,114$ & $-18,585$ & 0,126 & 0,042 & 6,819 & 0,790 \\
Vtaper & $-0,089$ & $-14,600$ & 0,107 & 0,031 & 5,126 & 0,842 \\
VB1 & 0,050 & 8,155 & 0,085 & 0,011 & 1,821 & 0,944 \\
\hline
\end{tabular}

Sumber (Source): Diolah dari data lapang (Compiled and analyzed from field data)

\section{Ketelitian model-model penduga volume pohon}

Model V4 menunjukkan performansi terbaik, karena lebih akurat (nilai $M E, P E \%$, dan $M A D$ paling rendah) dan lebih teliti (nilai MSEP, RE\% paling rendah dan EF paling tinggi), disbanding model-model lainnya dalam menduga volume pohon sengon (Tabel 5). Model terbaik berikutnya adalah $\mathrm{V} 3$ dan kemudian berturut-turut $\mathrm{V}_{\text {fa }}$, $\mathrm{V}_{\mathrm{B}}, \mathrm{V}_{\mathrm{T}}$, dan $\mathrm{V}_{\mathrm{fb}}$.

\section{Potensi kehilangan keuntungan petani}

Dalam sistem penjualan kayu sengon di lokasi penelitian, pengepul menanggung semua biaya pemanenan (penebangan, pemikulan, dan pengangkutan). Oleh karena itu, biaya pemanenan tersebut diperhitungkan dalam total harga jual untuk menganalisis potensi pendapatan penjualan kayu (Tabel 6).

Pada sistem penjualan kayu sengon per batang dan per luasan, berpotensi menimbulkan kehilangan keuntungan yang cukup besar bagi petani. Sistem penjualan kayu per batangan menimbulkan kehilangan keuntungan sebesar 24,99\%, sedangkan sistem penjualan kayu per luasan menimbulkan kehilangan keuntungan sebesar 32,19\% (Tabel 7). Hal ini menunjukkan bahwa sistem penjualan kayu dengan tanpa menghitung volume pohon atau tegakan sengon sesungguhnya sangat berpotensi menimbulkan kehilangan keuntungan bagi para petani hutan rakyat.

\section{B. Pembahasan}

Angka bentuk pohon merupakan salah satu komponen penentu volume pohon yang merupakan penggambaran dari bentuk batang. Tidak ada perbedaan yang signifikan antara angka bentuk buatan dan absolut sehingga keduanya mampu menjelaskan bentuk batang (Fadaei et al., 2008), tetapi masing-masing angka bentuk memiliki nilai akurasi yang berbeda. Angka bentuk yang sering digunakan adalah angka bentuk buatan karena $d b h$ biasa digunakan sebagai ciri diameter pohon (Simon, 1996). Namun, hasil penelitiaan menunjukkan bahwa angka bentuk absolut lebih akurat dalam menduga volume pohon dibandingkan angka bentuk buatan. Hal ini diduga karena pohon sengon di hutan rakyat tidak berbanir sehingga diameter pangkal mempunyai korelasi yang kuat dengan volume batang.

Tabel (Table) 6. Total harga jual kayu sengon (Total selling price of sengon)

\begin{tabular}{|c|c|c|c|c|c|c|c|}
\hline \multirow{2}{*}{$\begin{array}{l}\text { Sistem } \\
\text { Penjualan } \\
\text { (Selling } \\
\text { systems) }\end{array}$} & \multirow{2}{*}{$\begin{array}{l}\text { Luas } \\
\text { lahan } \\
\text { (Total } \\
\text { area) }\end{array}$} & \multirow{2}{*}{$\begin{array}{c}\text { Jumlah } \\
\text { (Total) }\end{array}$} & \multirow{2}{*}{$\begin{array}{c}\begin{array}{c}\text { Harga Jual }^{*} \text { (Price) } \\
(\mathrm{Rp})\end{array} \\
\end{array}$} & \multicolumn{3}{|c|}{$\begin{array}{l}\left.\text { Biaya-biaya }(\mathrm{Rp})^{*}\right) \\
\quad(\text { Cost })\end{array}$} & $\begin{array}{l}\text { Total Harga } \\
\text { Jual(Total of } \\
\text { selling price) }\end{array}$ \\
\hline & & & & $\begin{array}{c}\text { Penebangan } \\
\text { (Logging) }\end{array}$ & $\begin{array}{c}\text { Pemikulan } \\
\text { (Manual } \\
\text { Transportation) }\end{array}$ & $\begin{array}{l}\text { Pengangkutan } \\
\text { (Transportation) }\end{array}$ & (Rp) \\
\hline $\begin{array}{c}\text { per batang } \\
\text { (per log) }\end{array}$ & - & 1 & 500.000 & 40.000 & 23.000 & 20.000 & 583.000 \\
\hline $\begin{array}{l}\text { per luasan } \\
\text { (per area) }\end{array}$ & 500 & 43 & 15.000 .000 & 1.720 .000 & 1.290 .000 & 860.000 & 18.870 .000 \\
\hline
\end{tabular}

Sumber (Source): Diolah dari data lapang (Compiled and analyzed from field data)

Keterangan (Remarks): *Informasi harga dan biaya diperoleh dari tengkulak local 
Tabel (Table) 7. Kehilangan keuntungan petani (Profit loss for the farmers)

\begin{tabular}{|c|c|c|c|c|c|c|c|c|}
\hline \multirow[t]{2}{*}{$\begin{array}{l}\text { Sistem } \\
\text { penjualan } \\
\text { (Selling } \\
\text { system) }\end{array}$} & $\begin{array}{l}\text { Kelas } \\
\text { diameter } \\
\text { (Class of } \\
\text { diameter) }\end{array}$ & Volume & $\begin{array}{c}\text { Harga/m3*) } \\
\quad \text { (Price) }\end{array}$ & $\begin{array}{l}\text { Total harga } \\
\text { (Total price) }\end{array}$ & $\begin{array}{c}\text { Total harga } \\
\text { hitung (Total } \\
\text { count) }\end{array}$ & $\begin{array}{c}\text { Total harga } \\
\text { jual }^{* *} \text { (Total } \\
\text { of selling } \\
\text { price) }\end{array}$ & $\begin{array}{c}\text { Potensi } \\
\text { kehilangan } \\
\text { keuntungan } \\
\text { (The } \\
\text { potential loss } \\
\text { of profits) }\end{array}$ & $\begin{array}{c}\text { Persentase } \\
\text { (Persentage) }\end{array}$ \\
\hline & $(\mathrm{CM})$ & (m3) & $(\mathrm{Rp})$ & $(\mathrm{Rp})$ & $(\mathrm{Rp})$ & $(\mathrm{Rp})$ & $(\mathrm{Rp})$ & $(\%)$ \\
\hline \multirow[t]{2}{*}{$\begin{array}{l}\text { Per batang } \\
(\text { Per log })\end{array}$} & $30-39$ & 0,82 & 950000 & 777239.29 & 777239.29 & 583000 & 194239.29 & 24,99 \\
\hline & $15-19$ & 1,21 & 600000 & 723172,36 & 27827700,05 & 18870000 & 8957700,05 & 32,19 \\
\hline Per luasan & $\begin{array}{l}20-24 \\
25-29\end{array}$ & $\begin{array}{l}3,46 \\
3,47\end{array}$ & $\begin{array}{l}760000 \\
870000\end{array}$ & 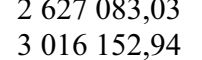 & & & & \\
\hline \multirow[t]{3}{*}{ (Per area) } & $30-39$ & 14,93 & 950000 & 14184130,10 & & & & \\
\hline & $40-49$ & 4,70 & 1020000 & 4796942,53 & & & & \\
\hline & $50-155$ & 2,36 & 1050000 & 2480219,09 & & & & \\
\hline
\end{tabular}

Sumber (Source): Diolah dari data lapang (Compiled and analyzed form field data)

Keterangan (Remarks): *Informasi harga diperoleh dari sumber PT ASA TIMBER

**Informasi harga diperoleh dari pengepul lokal

Fungsi taper juga dapat menduga volume batang pohon dengan menerapkan teknik integral (Bluhm et al., 2007, Harbagung \& Krisnawati, 2009). Kelebihan penggunaan taper dapat menentukan volume pohon pada berbagai ketinggian atau panjang yang dikehendaki, selain itu dari persamaan taper juga dapat menghasilkan angka bentuk batang. Nilai ketelitian persamaan taper lebih rendah $(\mathrm{EF}=84,2 \%)$ dibandingkan dengan model volume V3 ( $\mathrm{EF}=95,5 \%), \mathrm{V} 4(\mathrm{EF}=97,2 \%)$, dan angka bentuk absolut ( $\mathrm{EF}=94,6 \%)$. V4 merupakan model volume dengan akurasi dan ketelitian tertinggi dengan nilai bias terkecil $(\mathrm{ME}=$ $0,009, \mathrm{PE}=1,55 \%$ ), ini menunjukkan bahwa variabel tinggi memiliki hubungan yang erat de- ngan volume pohon. Namun penggunaan model V4 di hutan rakyat kurang praktis karena petani harus mengukur tinggi pohon selain diameter pohon. Oleh karena itu, model V3 disarankan untuk digunakan di hutan rakyat karena petani hanya mengukur diameter untuk menduga volume pohon sengon. Selain memiliki akurasi yang tinggi (Gambar 1), V3 juga praktis digunakan petani di hutan rakyat. Jika petani hutan rakyat tidak mampu menyusun model volume karena keterbatasan alat, maka opsi penentu volume yang mungkin dilakukan adalah dengan menggunakan angka bentuk absolut, karena Vfa juga menunjukkan nilai akurasi yang baik dalam menduga volume pohon (Gambar 1).

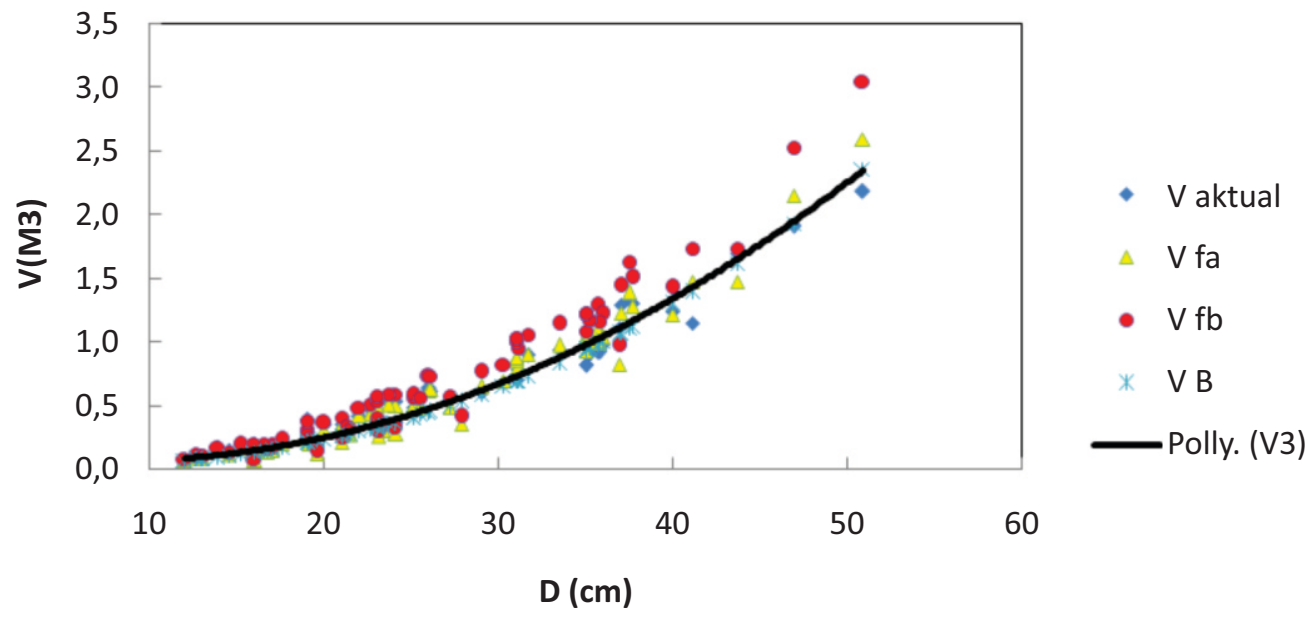

Sumber (Source): Diolah dari data lapang (Compiled and analyzed form field data)

Gambar (Pigure) 1. Perbandingan nilai-nilai dugaan volume (Comparison of volume estimation value) 
Proses penjualan sengon di lokasi penelitian tidak menghitung dimensi pohon dalam menetapkan harga. Jual beli dilaksanakan melalui proses tawar menawar harga antara pengepul dengan petani. Pengepul memegang peranan kunci sementara petani memilki peran yang rendah dalam tata niaga kayu (Siswoyo, 2007). Pengepul menetapkan harga berdasarkan pendugaan tanpa mengukur pohon. Praktek penjualan tersebut menimbulkan kesalahan penghitungan nilai kayu. Kesalahan nilai kayu akan merambat kepada harga jual. Perbandingan nilai kayu antara praktek penjualan yang dilakukan dengan nilai kayu berdasarkan volume pohon menunjukkan bahwa petani di hutan rakyat mengalami kehilangan keuntungan sebesar 24,99\% untuk penjualan per batang, dan $32,19 \%$ untuk per luasan. Hal ini menunjukkan bahwa sistem penjualan kayu tanpa menghitung volume pohon atau tegakan sengon sesungguhnya sangat berpotensi menimbulkan kehilangan keutungan bagi para petani hutan rakyat.

\section{KESIMPULAN DAN SARAN}

\section{A. Kesimpulan}

Volume pohon sengon di hutan rakyat dapat diduga secara akurat dan teliti melalui model $\mathrm{V}=0,000213 \mathrm{D}^{2,37}$. Sistem penjualan kayu sengon yang lazim diterapkan di hutan rakyat yang menggunakan sistem penjualan kayu per batang menimbulkan potensi kehilangan keuntungan sebesar 24,99\%, sedangkan yang menggunakan sistem penjualan kayu per luasan kehilangannya sebesar $32,19 \%$.

\section{B. Saran}

Penelitian ini memiliki batasan dalam pemilihan pohon contoh yaitu pohon lurus, sementara jenis pohon sengon terdiri dari berbagai macam bentuk arsitektur. Oleh sebab itu, perlu penelitian lebih lanjut untuk penyusunan model volume pohon dalam berbagai macam arsitektur untuk areal hutan rakyat yang lain dalam rangka meningkatkan ketelitian dalam penyusunan model volume pohon.

\section{UCAPAN TERIMA KASIH}

Disampaikan ucapan terima kasih kepada Bapak Mansur dan Bapak Afdal yang telah membantu dalam pelaksanaan penelitian dan pengumpulan data di lapangan.

\section{DAFTAR PUSTAKA}

Bluhm, A.A., Garber, S.M., \& Hibbs, D.E. (2007). Taper equation and volume tables for plantation-grown red alder. Washington: Oregon State University.

Bustomi, S., Harbagung, \& Krisnawati, H. (1995). Tabel isi pohon lokal jenis Sengon (Paraserianthes falcataria) di KPH Bogor, Indonesia. Buletin Penelitian Hutan, $588,37-57$.

Chave, J., Condit, R., Aguilar, S., Hernandez, A., Lao, S., \& Perez, R. (2004). Error propagation and scaling for tropical forest biomass estimates. Perancis: The Royal Society.

Diniyati, D., Santoso, H.B., \& Ruhimat, I.S. (2009). Peran hutan rakyat dalam meningkatkan kesejahteraan masyarakat di sekitar Hutan Gunung Sawal. Balai Penelitian Kehutanan. p. 89-101.

Draper, N.R., \& Smith, H. (1992). Analisis regresi terapan. Gramedia. Jakarta.

Fadaei, F., Fallah, A., Latifi, H., \& Mohammadi, K. (2008). Determining the best form factor formula for Loblolly Pine (Pinus taeda L.) plantations at the age of 18 , in Guilan-northern Iran. Journal of Environmental Sciences, 6(1),19-24.

Harbagung, H., \& Krisnawati. (2009). Model taper batang tanaman Khaya anthoteca C.DC. di Hutan Penelitian Pasirhantap Sukabumi, Jawa Barat. Jurnal Peneltian Hutan dan Konservasi Alam, 6(1),13-24.

Huang, S., Yang, Y., \& Wang, Y. (2003). A critical look at procedures for validating growth and yield. In: Amaro A., Redd D., Soares P. (eds) Modelling forest systems. Guildford: CABI Publishing, p. 271-293.

Husch, B., Beers, T.W., \& Kershaw, J.A. (2003). Forest mensuration. Florida: The Ronald Press Company.

Kurinobu, S., Prehatin, D., Mohammad, N., \& Matsune, K. (2007). A stem taper equation compatible to volume equation for Paraserianthes falcataria in Pare, East Java, Indonesia: its implications for the plantation management. Journal of Forest Research, 12, 473-478. 
Kusmedi, P., \& Jariyah, N.A. (2010). Analisis finansial pengelolaan agroforestri dengan pola sengon kapulaga di Desa Tirip, Kecamatan Wadaslintang, Kabupaten Wonosobo. Jurnal Penelitian Sosial dan Ekonomi Kehutanan, 7(2), 93-100.

Muhdin, \& Hakim, A.R. (2004). Penentuan jumlah pohon contoh minimal untuk penyusunan persamaan volume melalui fungsi taper. Jurnal Manajemen Hutan Tropika, 10(2), 22-33.

Nugroho, B., Tiryana, T. (2013). Implications of the private property right to the community forest businesses formalization through the certification policy. Jurnal Manajemen Hutan Tropika, 19(3), 178-186.

Pemerintah Daerah Bogor. 2010. Monografi Desa Karyasari. Bogor: Bogor.

Prihadi, N., Darusman, D., Nugroho, B., \& Wijayanto, N. (2010). Kelembagaan kemitraan industri pengolahan kayu bersama rakyat untuk membangun hutan di Pulau Jawa. Jurnal Penelitian Sosial dan Ekonomi Kehutanan, 7(2), 127-138.
Simon, H. (1996). Metode Inventore Hutan. Yogyakarta: Penerbit Aditya Media.

Siswoyo, B. (2007). Hutan rakyat dan serbuan pasar: Studi refleksi pengusahaan hutan rakyat lestari secara kolaboratif di Pacitan, Jawa Timur. Jurnal Ilmu Sosial dan Ilmu Politik, 2(2), 153-286.

Sprugel, D.G. (1983). Correcting for bias in logtransformed allometric equations. Journal Ecology, 64(1), 209-210.

Spurr, H. (1952). Forest Inventory. New York: The Ronald Press Company.

Tiryana, T., Tatsuhara, S., \& Shirashi, N. (2011). Empirical models for estimating the stand biomass of teak plantations in Java, Indonesia. Journal of Forest Planning, 16, 177-188.

Yang, Y., Robert, A., Monserud, \& Huang, S. (2004). An evaluation of diagnostic test and their roles in validating forest biometric models. Journal of Forest Research, $34,619-629$. 